\title{
REAPPORTIONMENTS OF STATE LEGISLATURES- LEGAL REQUIREMENTS
}

\author{
LASHLEY G. HaRveY*
}

The problems which face state legislatures are not unlike those which plague all legislative bodies in our time. As far as the domestic scene is concerned, they are an outgrowth of our rapid urbanization and industrialization and call for readjustment between employer and employee, social legislation, housing, and replanning of large metropolitan communities. These questions in themselves prove upsetting enough to vested interests and give cause for factional disputes. Social and economic lines are sharply drawn and the situation is futher complicated as state governments discover rich sources of revenue from expanding business activities, sales, and income, at a time when local treasuries are rapidly being depleted. There is a widespread feeling that these questions could be resolved satisfactorily for the majority of the people if state legislatures were allowed to keep abreast of the times through a periodic and systematic plan of reapportionment. Minority domination of legislative assemblies effectively frozen into state constitutions is a denial of the democratic principle. Inequalities of representation are most noticeable in the clash between rural and urban interests, although it is oversimplification to maintain that the present conflict over state constitutional measures regarding reapportionment is solely rural vs. urban. Large taxpaying interests frequently gain from rural domination and will go to great lengths to maintain existing apportionments.

Faced with rural-urban conflicts, state constitutional conventions have compromised in favor of rural domination of at least one house and frequently of both, evading rather than providing a solution. Usually this takes the form of making the county the principal legislative district, which plays directly into the hands of the courthouse gang. In those states which make the county a unit of political party organization and a district for selection of delegates to the state constitutional conventions, reapportionment which would change county control is rare. The system is self perpetuating and is a bold affront to popular government in the silent gerrymandering by county- or town-dominated legislatures which fail to reapportion at the times specifically prescribed in their constitutions.

Some argue that the best solution would be to recognize the two major interests -area and population-by proposing a federal plan for state legislatures. The senate would be representative of area or the county interests and the house would represent population as a concession to urban interests. Such a plan is likely to result

* A.B. 1925, William Jewell College; A.M. x930, Stanford University; Ph.D. 1942, Harvard University. Maxwell Professor of Government and Citizenship, Chairman, Department of Government, Dircctor, Institute of Public Service, Boston University. Senior Fulbright Scholar, Visiting Professor, London School of Economics and Political Science, 1951-1952. 
in deadlock, especially since the governor is elected by the entire state. It would be difficult for any governor to get through his program with such a legislature if the state contained several large cities. One need only to study the political history of Connecticut to see how ineffectively the federal system works. With house representation based on towns and senate on counties, with seats distributed according to population, inaction and stalemate is common. The federal plan is hardly applicable to states. It will be recalled that it was not considered the best system at Philadelphia but was a compromise between large and small states. On the other hand, if the federal plan is rejected and both houses represent population instead of different interests the argument for two houses loses validity. A unicameral legislative body as adopted by Nebraska may be a better solution. Neither the federal principle nor unicameralism may be written permanently into a constitution with any assurance that all interests will be served adequately for any length of time. Irrespective of the emphasis placed upon interest groups served by a policy of representation, no legislature may effectively play its role unless it is permitted to be representative. Government by consent, a revolutionary theory of the seventeenth and eighteenth centuries, is extremely difficult to operate in the twentieth. Granting this difficulty, it remains the underlying principle of our democratic system. A closer examination of state constitutions and practices may disclose avenues to a solution.

\section{Reapportionment in State Constitutions}

All states make some provision for apportionment of seats in the legislature. Usually population is the principal factor for assignment of more than one seat to a district. A few constitutions, as those of Arizona, Delaware, and Mississippi, establish districts and apportion seats among them. All other constitutions provide for redistricting and reapportionment. Redistricting is the process of laying out areas for representation and reapportionment is the act of allotting representation to these areas. In our federal system apportionment for Congress is an act of the national authorities but redistricting is left to the states. In the states the legislature may perform both functions and frequently the terms are used interchangeably. The Colorado constitution draws a clear line of distinction, but the California constitution uses the term "apportionment" for the creation of single-member districts. It is not uncommon to find both the legislature and courts referring to the establishment of districts as "apportionment acts." This confusion in terms prevents a clear division of responsibility for these two distinct functions.

To consider first, reapportionment-the allocation of seats to districts-what criteria should be used? Should all the people be counted as the basis for distribution; or only citizens; or only the qualified voters; or those who bother to vote? Concerning this there is no complete agreement among the states.

Population is the most frequently used basis and, contrary to most opinion, it is more commonly used as the basis for distribution of seats in the state senate than 
in the house. Twenty-four states specify in their constitution that population shall serve as the basis for reapportionment of the senate, although in 5 of theseAlabama, Florida, Iowa, West Virginia, and Pennsylvania-the effectiveness of the population factor is practically nullified because of limits placed upon the number of senators a political unit may have. ${ }^{1}$ Certain other variations of population occur. Nine states exclude Indians not taxed. ${ }^{2}$ Adult males are specified in Indiana, ${ }^{3}$ and Oregon limits population to white population. ${ }^{4}$ The remaining states have further variations and limitations, a progressive formula, or limitation of one senator to each county. 5

Population is prescribed in 21 state constitutions as the basis for reapportionment of the lower chamber, ${ }^{6}$ although this is limited in 9 others by excluding Indians not taxed or military personnel; ${ }^{7}$ is restricted to white population in one; ${ }^{8}$ and to adult males in another. ${ }^{9}$ Twelve states either permanently prescribe the distribution of representatives or provide inelastic formulas. ${ }^{10}$

Apparently some states do not consider mere population as a standard upon which distribution of legislators can be made sufficient for a popularly controlled govern-

\footnotetext{
1 The article and section of the state constitution: Ark. Const. Art. VIII, $\$ \S 1-5$; Colo. Const. Art. V, $\$ \$ 45-49$; Conn. Const. Art. III, $\$ \$ 3,4$; GA. Const. Art. III, $\$ 2$ (Pars. ii and iii), \$3 (Par. i); ItL. Const. Art. IV, $\$ 6,7,8$; Kan. Const. Art. II, $\$ 2$, Art. X, $\$ I-3 ; \mathrm{Kr}$. Const. \$33; LA. Const. Art. III, $\S \$ 2,5,6$; Mrch. Const. Art. V, \$\$2-4; Mo. Const. Art. III, \$\$2-II; Nev. Const. Art. I, \$13, Art. XVII, \$6; N. M. Const. Art. IV, \$42; N. D. Const. Art. II, \$\$29, 35, 42 Art. XVIII, \$\$214; OHIo Const.

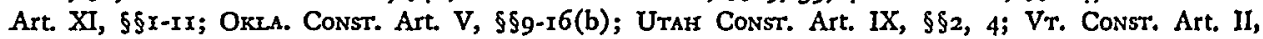
$\$ \$ 12,18,37$; VA. Const. Art. IV, $\$ 43$; Wro. Const. Art. III, $\$ 3$, Art. III-A, \$\$2-4. Although population is given as the basis in the remaining five its effectiveness is limited; e.g.: Not more than one senator per county: Ala. Const. Art. IV, \$50, Art. IX, \$\$I98-203; Fla. Const. Art. VII, \$\$3, 4; and Iowa. Const. Art. III, $\$ \$ 34,35$. Not more than two senators to any one county: West. VA. Const. Art. VI, $\$ \$_{4}-10$, 50. PA. Const. Art. II $\S \S I 6-I 8$, limits a city or county to not more than $1 / 6$ of the members of the senate. Cf. 8 THE BoOK OF THE STATES 1950-I95I, I2I-I 24 for the best summary.

${ }^{2}$ Cazlf. Const. Art. IV, $\$ 6 ;$ Me. Const. Art. IV, Pt. I, $\$ \$ 2,3$, Art. IV, Pt. II, $\$ 1$, 2; Minn. Const. Art. IV, $\$ \$ 2,23,24$, Sched. 10, I2; NeB. Consr. Art. III, $\$ 5 ;$ N. Y. Const. Art. III, $\$ \$ 3-5 ;$ N. C. Const.

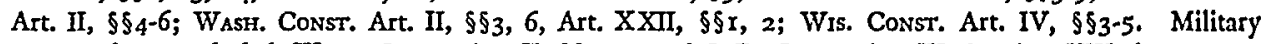
personnel are excluded, WAsr. Const. Art. II, \$\$2, 3; and S. D. Const. Art. III, $\$ 5$, Art. XIX, §2.

${ }^{3}$ Ind. Const. Art. IV, $\$ \$ 4-6$. This is of course overruled by U. S. Const. AMEnd. XIX.

Ore. Const. Art. IV, $\$ \$ 6,7$. This is nullified by U. S. Const. AMrend. XV.

Ionнo Const. Art. III, $\$ \$ 2,4,5$, Art. XIX, $\$$ I,2; Mont. Const. Art. V, $\$ 4$, Art. VI, $\$ 33-6 ;$ N. J. Const. Art. IV, §II, Par. I; Art. IV, §III, Par. I; N. C. Const. Art. II, $\S \S 1,2,3^{-6}$.

"Als. Const. Art. IX, $\$$ 198-203; Ark. Const. Art. VIII, $\$ \$ 1-5 ;$ Colo. Const. Art. V, $\$ \$ 45-49$; Ill. Const. Art. IV, $\$ \$ 6,7,8$; Ky. Const. $\$ 33$; LA. Const. Art. III, $\$ \$ 2,5,6$; Mrch. Const. Art. V, $\$ \$ 2-4$; Mo. Const. Art. III, $\$ 2-11$; Mont. Const. Art. V, $\$$, Art. VI, $\$ \$ 2-6$; Nev. Const. Art. XVII, $\$ 6$; N. H. Const. Pt. II, $\S 99$, Ir, 26; N. J. Const. Art. IV, §III, Par. I; N. M. Const. Art. IV, §(42); N. D.

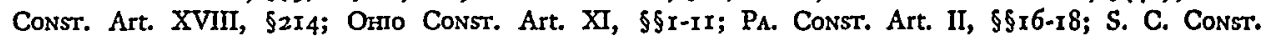
Art. III, $\S ฐ-2,3-6$; Utah Const. Art. IX, $\$ 2-4$; VA. Const. Art. IV, $\$ 43$; W. VA. Const. Art. VI, $\S \S 4-10,50 ;$ Wyo. Consr. Art. III-A, $\$ \$ 2-4$.

${ }^{7}$ Calif. Const. Art. IV, $\$ 6 ;$ ME. Const. Art. IV, Pt. II, $\$ 1,2$; Minn. Const. Art. IV, $\$ 2,23,24$, Sched. 10, 12; Neb. Consr. Art. III, $\$ 5 ;$ N. Y. Consr. Art. III, $\$ \$ 3-5 ;$ N. C. Const. Art. II, \$\$4-6; S. D. Const. Art. XIX, §2; Wash. Const. Art. XXII, $\$$ I, 2; WIs. Const. Art. IV, \$\$3-5.

${ }^{8}$ Ore. Const. Art. IV, $\$ \$ 6,7$. Obsolete since the passage of U. S. Const. Amend. XV.

- IND. Const. Art. IV, $\$ \$ 4,5,6$. Obsolete with the passage of U. S. Const. AMEnd. XIX.

${ }^{10}$ Cons. Const. Art. III, $\$ \$ 3,4$, Amendments II, XV, XVII, XXXI; Dela. Const. Art. II, \$2; FLA. Const. Art. VII, \$\$3, 4; Ga. Const. Art. III, \$2, Pts. ii, iti, Pt. i, \$3; IDaho Const. Art. XIX, \$\$1, 2; Iowa Const. Art. III, \$\$34, 35; Mp. Const. Art. III, \$\$2, 5; Miss. Const. Art. XIII, \$\$254-256; OkLA. Const. Art. V, \$\$9-I6(b); R. I. Const. Art. XIII, Amend. XIX; T'EXıs Const. Art. III, \$\$25-26a, 28; Vr. Const. Art. II, $5 \$ 13,18,37$.
} 
ment. Representation should be made upon a more dynamic basis, recognizing those who take part in government. For example, registered or legal voters are counted in Massachusetts and Tennessee for representation in both houses. ${ }^{11}$ Kansas allots one senator to each county in which at least 250 legal votes were cast for any candidate in the last preceding election, and Arizona apportions its lower chamber upon the official canvass of votes cast for all candidates for governor at its last election. ${ }^{12}$

Except for New Hampshire which apportions its senate upon the basis of direct taxes paid, ${ }^{13}$ in all other states population, or the politically active population, is the principal criterion for reapportionment. A hasty examination may lead one to conclude that the principle that each legislator represents approximately the same number of persons within each state is carried out in practice. This is far from the truth. The principle is made inoperative in many states either because representation by counties is allotted in state constitutions, often accompanied by measures which restrict the more populous counties, or because of the redistricting process itself.

Only one state, Delaware, has specified in its constitution adopted in r897 both the apportionment and districts for both houses. ${ }^{14}$ By specific constitutional provision Arizona apportions its senate by counties, ${ }^{15}$ and Louisiana apportions its representatives by parishes. ${ }^{16}$ Eleven other states accomplish the same results for the senate ${ }^{17}$ and 23 for the lower chamber ${ }^{18}$ by allotting at least one member to a political subdivision-county, town, or parish. These provisions invariably result in over-representation of the least populated areas. A few states discriminate more directly by denying the more populous districts their proportionate share of legislators. This is done in various ways: in one state by a system which requires: a substantial increase above the ratio for each succeeding legislator $;^{19}$ in 6 others each county is assured a member but the fractions of a ratio are placed so high that additional membership is denied the highly populated districts; $;^{20} 3$ states have fixed a maximum number of seats in their constitution (by assuring each county at least

${ }^{21}$ Mínss. Const. Pt. II, Ch. I, §III, Art. I, Amendment IXXI; Tenn. Consr. Art. II, $\$ 4,6$.

${ }^{12} \mathrm{KAN}$. Const. Art. II, $\$ 2$ as amended, Art. X, $\$$ I-2; ArIz. Consr. Art. IV, $\$ 2, \mathrm{I}$ (I) (no district may suffer a reduction below a quota based upon the election of 1930).

${ }^{18}$ N. H. Const. Pt. II, $\$ \$ 9$, II.

${ }^{10}$ Ariz. Const. Art. IV, Pt. 2, Pt. I(I).

${ }^{10}$ LA. CoNst. Art. III, $\S \S 3,5$.

${ }^{17}$ Each county assured one senator in Connecticut, Idaho, Maine, Maryland, Montana, New Jersey, Oregon, South Carolina, Vermont, and Wyoming. Rhode Island assures each town one senator.

${ }^{18}$ Each county is allotted one representative in Alabama, Arizona, Arkansas, Florida, Georgia, Idaho, Maryland, Michigan, Mississippi, Missouri, New Jersey, New York, North Carolina, Ohio, Oklahoma, Pennsylvania, South Carolina, Utah, and Wyoming. Each town in Connecticut and Vermont is assured one representative. New Hampshire assures every town of 600 people one representative at every sessinn and all towns smaller than 600 are assured representation within a ten year period in proportion to their size. Louisiana guarantees one renresentative to each parish.

${ }^{10}$ Florida (house). Cf. Dovell, Apportionment in State Legislatures: Its Practice in Florida, 7 Economic leaflets No. 3 (Bureau of Economics and Bustness Riesearch, College of Business AdminISTRATION, UNIVERSITY OF FLORIDA, 1948).

${ }^{20}$ Iowa (house); North Carolina (house); Oklahoma (house); Texas (house); Maine (house); Maryland (house). 
one seat few seats are left for distribution to the larger districts upon a population basis) $;{ }^{21} 5$ states have limited the maximum number of legislators any district may have, irrespective of population. ${ }^{22}$

Those states which have written into their constitutions such restrictive provisions make the constitutional convention the real apportioning authority and often the districting authority as well. The dead hand of the past stands as a legal block to reapportionment. Only Colorado, Illinois, Indiana, Massachusetts, Minnesota, Nebraska, Nevada, New Mexico, North Dakota, South Dakota, Tennessee, Virginia, Washington, and Wisconsin have no such limiting clauses and allow the apportioning authority to apportion both houses among established districts or among districts that may be created. ${ }^{23}$ Nine other states have no limiting constitutional restrictions upon the authority to reapportion or redistrict for the senate, ${ }^{24}$ but only 4 have permitted such freedom with the lower chamber..$^{25}$ It is surprising that the lower chamber in our state legislatures should be less likely to reflect population growth than the state senate.

State constitutions devote a great deal of space to the prevention of gerrymandering. Twenty-six states require that the territory be contiguous $;^{20} 9$ specify compactness; ${ }^{2 \pi}$ I 8 require "equality as nearly as may be"; ${ }^{28} 6$ do not permit counties to be divided in making districts; ${ }^{29} 4$ permit such division but only if the districts are contained within a county; ${ }^{30}$ and 6 have provisions against dividing other political units. ${ }^{31}$ These provisions against gerrymandering are quite well observed. Political parties are jealous of their interest in the matter and will rarely allow

${ }^{21}$ Alabama (house); New York (house); North Carolina (house).

${ }^{22}$ California - no county or city and county may have more than one senator; Connecticut-cach town of 5,000 may have not more than two members of the house; Maryland-Baltimore is limitcd to six senators; Pennsylvania-a district is limited to four representatives; Rhode Island-a limit of six senators is set for any town and no town or city may have more than one-fourth of the total members of the House of Representatives.

${ }^{23}$ Reapportionment is affected by other considerations than population in some of these states, viz.: Massachusetts provides that distribution shall be upon the basis of registered voters; Minncsota cxcludes non-taxable Indians; South Dakota excludes soldiers and officers of the U. S. Army and Navy; Tennessec limits reapportionment consideration to qualified electors; Washington excludes non-taxed Indians and soldiers and officers of the U. S. Army and Navy; Indiana considers only adult males (nullificd by Amendment XIX to U. S. Constitution).

24 Arkansas, Georgia, Kansas, Kentucky, Louisiana, Missouri, North Carolina, Ohio, and Oklahoma.

${ }^{25}$ Arizona uses votes cast for governor in previous election but assures that no district will lose representation based upon the r 930 election; California considers population exclusive of persons ineligible for naturalization; Kentucky uses population, but does not permit counties to be joined; Montana bases its reapportionment entirely upon population.

${ }^{20}$ Alabama, Arkansas, California, Colorado, Connecticut, Florida, Illinois, Indiana, Iowa, Kentucky, Massachusetts, Missouri, Nebraska, New Mexico, New York, North Carolina, North Dakota, Oklahoma, Oregon, Pennsylvania, Tennessee, Texas, Utah, Washington, West Virginia, and Wisconsin.

${ }_{2 \pi}$ Colorado, Illinois, Missouri, Nebraska, New York, North Dakota, Oklahoma, Pennsylvania, and West Virginia.

${ }^{28}$ Alabama, Arkansas, Connecticut, Florida, Illinois, Kentucky, Massachusetts, Minnesota, Missouri, Nebraska, New York, North Carolina, North Dakota, Oklahoma, Pennsylvania, Texas, West Virginia, and Wyoming. Equality may be implied in other provisions in some states.

${ }^{20}$ Indiana, Iowa, Louisiana, Oregon, Tennessee, and West Virginia.

${ }^{30}$ California, Illinois, Kentucky, and Oklahoma.

${ }^{31}$ Connecticut, Maine, Massachusetts, New Hampshire, Louisiana, and Vermont. 
anything resembling gerrymandering on the part of the opposite party to go unchallenged. Litigation is frequent and few flagrant examples of gerrymandering exist for any long period.

Forty-two state constitutions empower reapportionment of one or both houses after either the federal or state census, and the state legislature is the reapportioning authority in all but 6 states, including Delaware which specifically defines district boundaries in its constitution. The governor reapportions the house in Maryland. The constitution makes no provision for reapportionment of the senate. Arkansas and Ohio have special commissions. ${ }^{32}$ The governor appoints a special commission for apportioning the senate in Missouri. Three states-Arizona, Missouri, and Massachusetts-empower officials to district for the house. ${ }^{33}$ Although the legislatures frequently do not carry out the mandate to reapportion, only California, South Dakota, and Texas provide for reapportionment by an ex officio committee when the legislature defaults, ${ }^{34}$ and Arkansas, New York, and Oklahoma have made the reapportionment act reviewable by a court.

An examination of constitutional measures providing for distribution of seats in our state legislature reveals variations in the adaptation of democratic theory to legal principle. This is to be expected in that all constitutions are likely to contain the compromises of local conflicts. It is a surprise that these variations are not more pronounced. Except for Arizona, there is no state constitution which makes apportionment automatic, and Arizona only provides it for the lower chamber, making county boards the districting authority. There is much greater concern for the districting process in all state constitutions and the problem of gerrymandering which might result than for the mathematical task of apportionment. Much recognition is given to population as the principal factor of consideration in the distribution of seats to political subdivisions, such as the county, town, or parish, but the effect of population is greatly reduced if not almost completely denied by accompanying such provision with a maximum limit of seats available for reapportionment. Rather than provide representation of one leading but different interest in each house, most state constitutions permit one interest to dominate both houses, lending little support to bicameralism. This becomes even more obvious when one observes these interests within the states operating under constitutional fiat at some times and at others ignoring specific mandates.

\footnotetext{
${ }^{32}$ In Arkansas this commission consists of the secretary of state and attorney general. The action is subject to review by the supreme court. The governor, auditor, and secretary of state or any two of them constitute the commission in Ohio.

${ }^{33}$ County court in Missouri, county board of supervisors in Arizona, and county commissioners in Massachusetts.

"In California the commission consists of the governor, attorney general, sccretary of state, and superintendent of public instruction. This commission may be called into action by referendum if necessary. The governor, superintendent of public instruction, presiding judge of the supreme court, attorney general, and secretary of state constitute the commission in South Dakota. In Texas the governor, speaker of the house, attorney general, comptroller of public accounts, and the commissioner of the general land office form the committee with three constituting a quorum. Cf. McClain, Compulsory Reapportionment, 40 NAT. Munic. Rev. 305 (195I) for the recent Texas amendment.
} 


\section{Constitutional Provisions in Operatron}

The framers of state constitutions were either (I) distrustful of representative government under an extended franchise, or (2) convinced that county and area interests were so universal that the major problem was to assure adequate expression to the different types of rural interests. One may find support of both concepts by reading the proceedings of state constitutional conventions. Rural interests are protected far beyond the numerical importance of rural people. It is at this point that most criticism of reapportionment is launched. Perhaps county and area interests represent more than mere rural interests. County districts may serve also as tools of political party control. Political leaders and vested interests find county delegations responsive to their direction. If legislative bodies are to represent changing interests most state reapportionment plans may be criticized as being rigid and insensitive to the popular will.

The first reason for rigidity is the use made of county and other political subdivisions as legislative districts. With 23 states assuring representation by political subdivision in the house and II in the senate, little discretion is allowed for reapportionment. ${ }^{35}$ Under the guise of preventing gerrymandering by prohibiting division of these political units for the formation of new districts, local governmental units are made impregnable. ${ }^{38}$ This is especially effective in those states which specify a maximum number of legislators. ${ }^{37}$ Where ratios are provided each county may be granted representation if it has a fraction of a ratio. The Michigan constitution provides that "each county, with such territory as may be attached thereto, shall be entitled to a separate representative when it has attained a population equal to a moiety of the ratio of representation." ${ }^{38}$ The moiety clause is in direct conflict with the constitutional specification that the districts contain an equal number of inhabitants since a maximum of noo members for the house is also stipulated in the constitution. The use of fractional ratios is less discriminatory as it approaches a whole number. Illinois allots a representative to districts containing four-fifths of a ratio. Ohio and New Hampshire permit part-time representation.

A few illustrations will indicate the inequalities which have arisen in some of the states which have assigned representation to certain political units. In California where the senate is apportioned among counties, no county, or city and county, may contain more than one district although small counties may be grouped into districts. Based on the r 940 census, Los Angeles county with its population of $2,785,643$ was entitled to one senator and the district of Inyo and Mono counties with a population of 9,923 also was granted one senator. ${ }^{39}$ In Connecticut, which allows each

\footnotetext{
${ }^{85} \mathrm{Cf}$. notes 17 and 18 supra. $\quad{ }^{36} \mathrm{Cf}$. notes 29 and 30 supra.
}

${ }^{37}$ N. C. Const. Art. II, \$5; Fus. Const. Art. VII, $\$ 3$. For an excellent discussion of this problem, see Durfee, Apportionment of Representation in Legislatures: A Study of State Constitutions, 43 Mictr. L. REv. IOgI (1945); also Walter, Reapportionment of State Legislative Districts, 37 ILL. L. REv. 20 (1942). 73 (I94I).

${ }^{3}$ Mrch. Const. Art. V, \$3. Cf. Shull, Reapportionment: A Chronic Problem, 30 Nat. Munic. Rev.

${ }^{30}$ McHenry, Urban Vs. Rural in California, 35 NAT. Munic. Rev. 350, 352 (1946). 
town one representative and towns of over 5,000 two, the largest city, Hartford, with II6,000 is given the same number as Colebrook which has only 547 people. ${ }^{40}$ In some instances large cities are openly discriminated against by limiting their representation. The New York constitution provides that "no county shall have more than one-third of all the senators, and no two counties or the territory thereof as now organized, which are adjoining counties, or are separated only by public waters, shall have more than one-half of all the senators." ${ }^{11}$ Baltimore is limited to 6 senators. Philadelphia is not allowed more than one-sixth of all state senators and Providence is prevented from having more than one-fourth of the senators of Rhode Island.

Various devices are employed to discriminate against the largest metropolitan center. On analyzing urban representation in state legislatures in I945, Douglas H. MacNeil found discrimination in 31 of 42 states studied. Only $x 7$ cities out of 67 studied were represented in proportion to their population; 44 were under-represented; and 5 were over-represented. The ro largest metropolitan centers were under-represented. Baltimore and St. Louis at that time had about half of the number they would have had, had population been the sole criterion; Detroit and Los Angeles had less than one-half; Chicago and New York were short by onefourth; and Boston, Cleveland, Philadelphia, and Pittsburgh were slightly under their share. ${ }^{42}$

Further discrimination against cities has come with the failure of state legislatures to reapportion-frequently referred to as silent gerrymandering. In judicial procedure a judge may not sit on a case in which he has an interest yet in legislative procedure assemblies are made the judge upon questions of reapportionment. Fortytwo states authorize reapportionment after each census and empower the legislature to conduct such reapportionment. ${ }^{43}$ In many cases it is mandatory ${ }^{43^{*}}$ yet between r 940 and 1950 only 18 states bothered to reapportion. ${ }^{44}$ Ten did not reapportion be-

10 This situation is aggravated by the fact that the Connecticut house was last reapportioned in 1818 .

¿1. N. Const. Art. III, $\$ 4$, as amended in r93I.

"2 MacNeil, Urban Representation in State Legislatures, 18 StATE GovernMeNT 59 (1945); see also MacNeil, Big Cities and States' Rights, 33 Survey GrapHIc 405 (1944).

${ }^{4}$ For exceptions to the practice of reapportionment by the legislature, see notes 32 and 34 supra.

\$32 This responsibility is assumed to be a continuous one in case one legislature fails, although only Florida and New York provide this in their constitutions. Cf. FLA. Const. Art. VII, $\$ 3 ;$ N. Y, Const. Art. III, \$4. A number of states provide that once a reapportionment has been made it cannot be changed until the next census, viz., Ala. Const. IX, $\$ 198$, 200; Colo. Const. Art. V, $\$ 47$; Conn. Const. Amend. II; LA. Const. Art. III, $\$ 6 ;$ ME. Const. Art. IV, $I$ I (3); Mrch. Consr. Art. V, $\$ \$ 3,4 ;$ Neb. Const. Art. III, $55 ;$ N. J. Const. Art. IV, \$4; N. Y. Const. Art. III, \$\$4, 5; N. C. Const. Art. II, $\$ 4$; OHIO Const. Art. XI, $\S \S \mathrm{I}, 4 ;$ OkrIA. Consr. Art. V, $\S 99$, rof; S. D. Consr. Art. III, $\$ 5 ;$ W. VA. Const. Art. VI, \$10. Several stipulate that suits may be brought in court to test reapportionment, viz., Ark. Const. Art. VIII, §5; Mass. Const. Art. LXXXI; N. Y. Const. Art. III, §5; OkIA. Const. Art. V, 510. A time limit for suits is provided by Massachusetts and Oklahoma.

"California (r94I), Florida (1945), Kansas (1943), Kentucky (1942), Maine (1941), Massachusetts (senate, 1948, house 1947), Michigan (I943), Missouri (I945), Montana (I94I), Nevada (I947), New Hampshire (I943), New Jersey (I94I), New York (I943), North Carolina (I94I), Oklahoma (I94I), South Carolina (1942), South Dakota (1947), Virginia (1948). New Hampshire and Rhode Island limit reapportionment to the house. In Indiana reapportionment is required every six years and in Kansas every five. In Arizona it is to occur six months before any general election if the previous election indicated a change. Cf. Margaret Greenfield, Legislative Reapportionment (Bureau of Punlic Administration, University of California, i95I). 
tween I930 and 1940. ${ }^{45}$ Mississippi's last reapportionment was made in I890, Delaware's in 1897, and in Illinois and Alabama the last was in Igor. Connecticut established its present apportionment for the lower chamber in 1818 and for the senate in Ig03. ${ }^{46}$

Complaining of the situation in Oregon, state senator Richard Neuberger wrote in I950, "I represent a Portland district. The city has grown 230 per cent in population since the last reapportionment in I9ro-but in all these forty years it has not received a single senator. Our state constitution requires that the legislature be reapportioned every ten years. This has been ignored for four decades." At another point he wrote, "I represent 8I,000 people. A few desks away sits a senator from a realm of sagebrush and mountains, and he represents 7,200 people."47 In Minnesota failure to reapportion has resulted in such wide disparities as one representative district containing 7,254 people and another with two representatives for I28,50I people. ${ }^{48}$ In Alabama the population for the northern cities has increased markedly in the past 30 years. One northern district with 140,420 people has one senator and another district with 58,621 is also allotted one senator. ${ }^{40}$ A worse situation exists in Oklahoma which has not reapportioned its senate since I90\%. One senator is allowed Tulsa county with r93,000 people and another Logan county with a population of only $25,000 .^{\mathbf{5 0}}$ Representative districts in Louisiana range from 7,203 to 50,427 people and senatorial districts from 19,598 to 155,503 . But these variations seem slight in comparison with the discrepancy between Duval county, Florida which has 3 representatives and 25 other counties with a total population equal to that of Duval which have 27 representatives. ${ }^{51}$

Some southern states have shown the greatest hesitancy to reapportion but the problem is not a regional one by any means. Illinois and New Jersey have poor records. Cook county in Illinois with 52 per cent of the state's population has 37.3 per cent representation in the legislature. Thirteen counties with one-fifth of the population of New Jersey have $x_{3}$ senators, while 8 counties containing four-fifths of the population have only 8 senators. $^{52}$

\section{Avenues of Action}

The courts offer little consolation to those who would coerce legislative bodies by mandamus to reapportion. It is generally conceded that the doctrine of separation

${ }^{45}$ Cf. Walter, supra note 37 .

${ }^{16}$ Kentucky reapportioned in 1942 but its previous reapportionment was as of 1893 . Cf. Neuberger, Our Rotten-Borough Legislatures, 86 SuRvey 53 (1950).

${ }^{47}$ Neuberger, supra note 46 . For a scholarly treatment of the Oregon situation, cf. Schumachcr, Reapportionment in Oregon, 3 Western PoL. Q. 428 (1950).

${ }^{48}$ Dorweiler, Minnesota Farmers Rule Cities, 35 Nat. Munic. Rev. II5, II6 (1946). Sce also Possible Improvement in the Operation of State Government (University of Minnesota, InstiTUTE of GovernMeNTAL Research Bult. No. 20) (1947).

${ }^{4}$ Hallie Farmer, Legislative Reapportionment (Bureau of Public administration, UniVERsity OF AlabaMa, 1944).

${ }^{50}$ Thornton and Brandenberg, Apportionment in Oklahoma, Okzahoma Constiturional. Studies (Orlahoma State Legislative Council, 1950).

${ }^{61}$ GreENFiELd, op. cit. supra note 44 , at $4 \mathrm{I}$. $\quad$ Es Id. at 42 . 
of powers makes legislatures immune and courts refuse to achieve the same results indirectly if not allowed to do so directly. ${ }^{53}$ On the other hand, courts are much more likely to review reapportionment acts. ${ }^{54}$

Arkansas, New York, and Oklahoma specifically delegate to the courts of the state the authority to review reapportionment statutes, ${ }^{55}$ but they have been reviewed in numerous instances in states where no specific authorization exists. Courts are inclined to regard limitations upon the reapportioning authority as of two typesmandatory and discretionary. Certain requirements and prohibitions are considered mandatory, namely: maximum number of legislators; areas within districts must be contiguous; specified subdivisions to be assigned one representative or senator; and prohibitions against division of political subdivisions. A certain amount of discretion is recognized on measures providing equal distribution "as nearly as may be" or compactness "as nearly as practical." 56

Reapportionment statutes are usually attacked by bringing actions for mandamus against the the secretary of state, county clerk, or other authority responsible for reapportionment. ${ }^{57}$ There is some question as to whether injunctions may be used. ${ }^{58}$ In the study of these cases it is noticeable that the courts are reluctant to challenge the legislature in its reapportioning function. ${ }^{59}$

It is frequently suggested that the people might resort to the initiative to force reapportionment. This has been tried with varied success. A Massachusetts court declared that the initiative and referendum were not applicable to the creation of state senatorial and representative districts. ${ }^{60}$ The Missouri supreme court nullified an apportionment by initiative. ${ }^{61}$ The only really successful attempt to secure reapportionment by initiative occurred in Colorado. Reapportionment had gone by default in both I920 and I930 and the people by popular vote in I932 adopted a new apportionment by initiative. At the next session of the legislature, seated under the

63 The principal cases establishing this point are: People ex rel. Woodyatt v. Thompson, 155 Ill. $45 \mathrm{I}$, 475, 40 N.E. 307 (1895); and State ex rel. Barrett v. Hitchcock, 24 I Mo. 433, I46 S. W. 40 (I9I2).

Et Arkansas amended its constitution to permit the use of mandamus. Cf. ARK. CoNsT. AMEND. 23, $\$ 5$.

it ARk. Const. Art. VIII, §5; N. Y. Const. Art. III, \$5; OkI. Const. Art. V, §1o.

to This distinction has been expressed in a number of cases, viz., People ex rel. Heffernan v. Carlock, 198 Ill. 150, 65 N. E. rog (1902); State ex rel. Attorney General v. Cunningham, 81 Wis. 440, 51 N. W. 724 (1892).

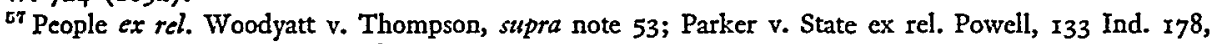
33 N. E. Irg (1893); State $e x$ rel. Williams v. Meyer, 20 N. D. 628, I27 N. W. 834 (1910); Baker County v. Benson, 40 Ore. 207,66 Pac. 8 I5 (rgor).

${ }^{E B}$ Fletcher v. Tuttle, $15 x$ Ill. 41,37 N. E. 683 (I894). The court held in this case that an injunction could not be used. However, injunctions have been granted in a number of states. $C f$. Denney v. State ex rel. Basler, I44 Ind. 503, 42 N. E. 929 (I896); Ragland v. Anderson, I25 Ky. I4r, 100 S. W. 865 (1907).

${ }^{\circ}$ This whole subject has been exhaustively treated by David D. Walter in Reapportionment of State Legislative Districts, 37 ILL. L. REv. 20 (1942), and by Elizabeth Durfee in Apportionment of Representation in Legislattres, 43 Mrch. L. Rev. I091 (1945). Cases continue to arise but no new patterns may be discovered.

${ }^{00}$ The opinion was requested on amendment XIVIII to the state constitution. Cf. In re Opinion of the Justices, 254 Mass. 617, 15 I N. E. 680 (x926).

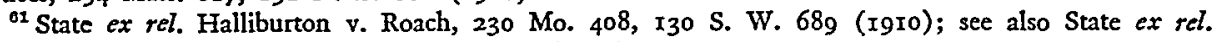
Lashly v. Becker, 290 Mo. 560, 235 S. W. Ior7 (I92r). 
old statute, it tried to nullify the new law by drafting its own. It erred by excessive discrimination against Denver and a few of the other cities and the act, when challenged in the Colorado supreme court, was declared void upon the ground of inequalities. $^{62}$

The great problem in the use of initiative or referendum always is to get people to act in their own interest. This is especially true on such technical questions as reapportionment. One of the best examples of these difficulties appeared in the struggle to secure reapportionment by initiative in California in I948. Professor Thomas S. Barclay of Stanford University has graphically described the situation under the IgII reapportionment act. "In I950," he wrote, "four counties containing 60 per cent of the population of the state have ro per cent of the senators, and 54 counties with 40 per cent of the population have go per cent of the senate membership. Estimates presented in 1948 indicated that, in the matter of taxation, $8 \mathrm{I}$ per cent of the use and sales tax receipts was paid from Io counties, while 94 per cent of the state income tax was paid by residents of ro counties. In the state senate where 6 per cent of the voters elect one-third of the members, a two-third vote is required to enact appropriation measures or to propose constitutional amendments."63 Yet with these startling figures before the electorate the proposed measure failed to carry a single county. ${ }^{64}$ Innumerable forces lined up to defeat the measure and spent $\$ 371,332$ as compared to $\$ 277,088$ spent in its support. ${ }^{65}$

The California experience not only illustrates the difficulties which may arise in using the initiative to secure reapportionment, but the great obstacle to any constitutional change of allotment of members to political subdivisions. States having such provisions face almost insurmountable handicaps in securing an equitable redistribution.

Initiative is a political solution to a problem which is not entirely political, although it possesses political elements. Certain steps in reapportionment lend themselves to objective treatment while political considerations must be recognized in others. The first step in reapportionment-division of the census count by number of available seats-is purely a mathematical problem which may be assigned to an administrative officer, as is the practice in Arizona and Massachusetts. In both states the secretary of state is required to certify the mathematical ratio. By assigning this routine task to an administrative officer it becomes automatic. Since there is no question of separation of powers the administrator is subject to mandamus in case of failure and for this reason it is better to assign the task to an administrative officer than to the chief executive, as is the practice in Maryland where the governor may reapportion the house. The governor of Maryland did not reapportion after the I940 census although the chief executive of the United States did act to reapportion Congress after the $195^{\circ}$ census. It is essential to make this feature automatic and

${ }^{02}$ Armstrong v. Mitten, 95 Colo. 425, 37 P. 2d 757 (1934).

${ }^{3}$ Barclay, The Reapportionment Struggle in California in 1948, 4 Western PoL. Q. 313, $314-315$ (I95I).

id. at 332 .

${ }^{6}$ Ibid. 
Arizona and Massachusetts have succeeded in doing so. In both states after notification by the secretary of state, county boards proceed to redraft district lines within their counties-recognizing the political element of districting. Although this prevents crossing county lines in order to form districts, it permits combinations of the less populated counties. Neither state has seen fit to follow the same procedure for redistricting the senate. The legislature redistricts the senate according to constitutional restrictions, and in Arizona the senate is specifically apportioned by counties in the constitution.

State commissions exist in Arkansas, Missouri, and Ohio, but none of these states was reapportioned after 1940. Missouri established its commission in 1945 and reapportionment of its senate was accomplished. California, South Dakota, and Texas provide boards or commissions which go into operation if the legislature fails to perform its task. California reapportioned its senate and South Dakota reapportioned both houses after 1940. Texas established its board as recently as I948 and the succeeding legislature (1950) reapportioned both houses, eliminating the necessity for action by the board. ${ }^{68}$

Districting may be regarded as more political than allotment and may be reserved to the legislature itself or delegated to a local body. County or local boards may be subject to mandamus. A state agency may be preferred, but experience indicates that such commissions are more likely to be effective if they become operative upon the failure of the legislature. There is no reason to assume that these commissions could not draw the district lines for they invariably contain enough elective officials to allow for certain political considerations after the mathematical ratio is certified. As administrative commissions they are subject to mandamus. The mathematical procedure is obviously mandatory although a certain amount of discretion in drafting district lines is recognized by the courts. This can be limited by the usual requirements of "equality as nearly as may be" and "compactness as nearly as practicable."

Changes in reapportionment procedure may be expected to be slow but now that Congress has led the way some states may follow. There are, nevertheless, good features of state reapportionment practices which could be adopted. The attempt of California in 1948 to secure reapportionment by initiative explodes the theory that rural interests are the only ones that prefer the present inaction on reapportionment within the states. In California four of the most populous counties voted against reapportionment two to one and Los Angeles county defeated the measure with almost as great force. ${ }^{67}$ Rejection of reapportionment in California cannot be laid to rural people. Similar forces exist in other states.

A constitutional amendment has been proposed in California which offers a new approach. While it does not suggest population as the criterion for reapportioning the senate, it allots the more populous counties more senators. Its sponsor has stressed "the under-representation on committees of senators from the heavily popu-

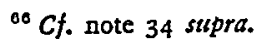

${ }^{\circ 7}$ Barclay, supra note 63 , at 322 . 
lated districts, and the lack of time and attention to consider important matters affecting these districts." ${ }^{\text {"88 }}$ This type of argument is convincing and one which legislators can understand.

It may be too much to expect that cities will be given full representation upon a population basis even where reapportionment reforms are achieved. Some have suggested more home rule for cities, removing many of the questions over which there is conflict. Few legislators are willing for the legislature to concern itself solely with area and rural problems. They much prefer to inject themselves into city politics where stakes are high.

Some would break off the large cities from states and create new city states. This suggestion reflects an inadequate conception of the interdependence of town and city.

The problem is basically one of achieving reapportionment more or less automatically. If discriminating features of state constitutions are not removed we can expect a greater use of initiative and referendum in the law making process within the states. We may also expect more pressure put on Congress for things city people need, such as public housing, social insurance, and more protection for labor. This is inevitable as Congress becomes more responsive to population shifts than state legislatures.

${ }^{88}$ Id. at 324 . 